\title{
Commentary: Born vein, you cannot die artery!
}

\author{
Michele Di Mauro, MD, $\mathrm{PhD}, \mathrm{MSc},{ }^{\mathrm{a}}$ and \\ Angela Di Baldassarre, $\mathrm{MD}, \mathrm{PhD}^{\mathrm{b}}$
}

The left internal thoracic artery (ITA) has been definitively demonstrated to be the best graft for coronary artery bypass grafting ${ }^{1}$; however, the need for multivessel revascularization is becoming more and more the rule in these procedures. Notwithstanding the evidence of an overwhelming superiority of bilateral ITA grafting relative to single ITA graft plus saphenous vein graft (SVG), surgeons are reluctant to embrace bilateral ITA grafting and continue to graft SVG. Analyzing data from the state of Virginia, LaPar and colleagues $^{2}$ found that bilateral ITA use from 2001 to 2013 was $3 \%$ in the overall bypass population and $6 \%$ in a subgroup of patients considered at "low risk" for bilateral ITA use. A recent analysis of the Society of Thoracic Surgeons database showed that bilateral ITA use was 3.5\% in 1999 and $4.1 \%$ in 2009 . $^{3}$

Unfortunately, the patency rates of vein grafts are worse than those of arterial grafts, either because of acute thrombosis patency rates of SVG by the first month or because of intimal hyperplasia and accelerated atherosclerosis, causing a reduction in long-term patency rate of $60 \%$. Many features have been found to be associated with low SVG patency, such as age, race, sex, hypercholesterolemia, diabetes mellitus, and chronic kidney disease. ${ }^{4-6}$ More recently, inflammation has been advocated to be responsible for vein graft disease because interleukin $1 \beta$ inhibition with canakinumab was able to target inflammation in vein graft disease. $^{6}$

The study by Sterpetti and colleagues ${ }^{7}$ provides further confirmation that a vein graft inserted into an arterial

\footnotetext{
From the ${ }^{a}$ Department of Heart Disease, SS Annunziata Hospital, Chieti, Italy; and bepartment of Medicine and Aging Sciences, University "G. D'Annunzio," Chieti-Pescara, Italy.

Disclosures: Authors have nothing to disclose with regard to commercial support. Received for publication Dec 23, 2019; revisions received Dec 23, 2019; accepted for publication Jan 3, 2020; available ahead of print Feb 4, 2020.

Address for reprints: Michele Di Mauro, MD, PhD, MSc Biostat, Heart Disease Department, SS Annunziata Hospital, Via dei Vestini, 66100, Chieti, Italy (E-mail: mdimauro1973@gmail.com).

JTCVS Techniques 2020;1:53-4

2666-2507

Copyright $(2020$ The Author(s). Published by Elsevier Inc. on behalf of The American Association for Thoracic Surgery. This is an open access article under the CC BY-NC-ND license (http://creativecommons.org/licenses/by-nc-nd/4.0/).

https://doi.org/10.1016/j.xjtc.2020.01.009
}

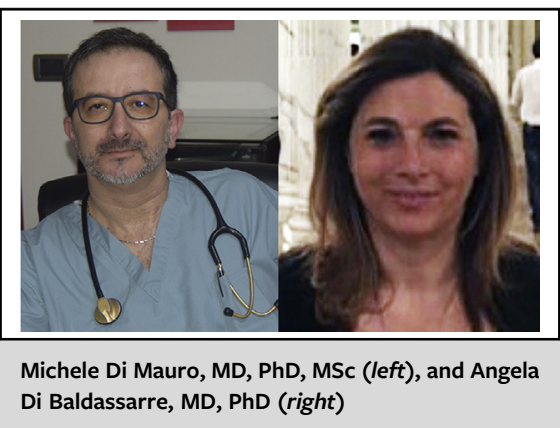

CENTRAL MESSAGE

This brief report should lead surgeons to reduce the grafting of coronary artery with saphenous vein grafts, increasing bilateral internal thoracic artery and radial artery use.

circulation remodels, increasing the internal diameter and the thickness of the wall as adaptive mechanism to higher internal pressure and larger quantities of blood. Inflammatory mediators are at the basis of this adaptive morphological change, leading SVG from a hyperplastic reaction to a true atherosclerotic plaque formation. In vein graft remodeling, not only endothelial cells are involved but also smooth muscle cells, which are activated, and components of the extracellular matrix in both the media and the adventitia, which are degraded.

These new findings explain why antiplatelet agents and statins are able to improve SVG patency in the long term, very likely as the result of a pleiotropic action, including anti-inflammatory effects. The take-home message of this brief report should be the need to reduce the grafting of coronary arteries with SVGs, to increase bilateral ITA and radial artery use, and to explore new anti-inflammatory agents to improve the patency of coronary artery bypass grafting whenever SVGs are used.

\section{References}

1. Loop FD, Lytle BW, Cosgrove DM, Stewart RW, Goormastic M, Williams GW et al. Influence of the internal-mammary-artery graft on 10-year survival and other cardiac events. N Engl J Med. 1986;314:1-6.

2. LaPar DJ, Crosby IK, Rich JB, Quader MA, Speir AM, Kern JA, et al; Investigators for the Virginia Cardiac Surgery Quality Initiative. Bilateral internal mammary artery use for coronary artery bypass grafting remains underutilized: a propensity-matched multi-institution analysis. Ann Thorac Surg. 2015;100:8-14; discussion 14-5.

3. ElBardissi AW, Aranki SF, Sheng S, O’Brien SM, Greenberg CC, Gammie JS Trends in isolated coronary artery bypass grafting: an analysis of the Society of 
Thoracic Surgeons adult cardiac surgery database. J Thorac Cardiovasc Surg. 2012;143:273-81.

4. de Vries MR, Simons KH, Jukema JW, Braun J, Quax PH. Vein graft failure: from pathophysiology to clinical outcomes. Nat Rev Cardiol. 2016;13:451-70.

5. de Vries MR, Quax PHA. Inflammation in vein graft disease. Front Cardiovasc Med. 2018;5:3.
6. Ridker PM, Everett BM, Thuren T, MacFadyen JG, Chang WH, Ballantyne C, et al; CANTOS Trial Group. Antiinflammatory Therapy with Canakinumab for Atherosclerotic Disease. N Engl J Med. 2017;377:1119-31.

7. Sterpetti AV, Sapienza P, Borrelli V, Di Marzo L. Inflammatory cytokines and experimental arterial and vein grafts. J Thorac Cardiovasc Surg Tech. 2020;1: 48-50. 